\title{
Differential Localization of Microtubules in Cerebellar Cells
}

\author{
Irith Ginzburg, ${ }^{1}$ Leah Behar, ${ }^{1}$ Uriel Z. Littauer, ${ }^{1}$ and W. Sue T. Griffin ${ }^{2}$ \\ 'Department of Neurobiology, The Weizmann Institute of Science, 76100 Rehovot, Israel, and 2Department of Pediatrics \\ and Anatomy, University of Arkansas for Medical Sciences, Little Rock, Arkansas 72205
}

\begin{abstract}
The distribution and subcellular localization of microtubules in rat brain cerebellum was analyzed by immunohistochemistry with antibodies prepared against 3 synthetic peptides corresponding to the $\mathrm{C}$-terminal region of $\beta$-tubulin. The peptides used correspond to amino acid positions $416-425$ (peptide 1), 416-431 (peptide 2), and 426-445 (peptide 4). The antibodies thus obtained displayed a remarkable specificity in reacting with different cell types in the rat cerebellum. Antibodies directed against peptide 1 primarily stained Purkinje cells and their dendrites and axons. Peptide 2 antibodies preferentially stained the glomeruli, while antibodies directed against peptide 4 preferentially stained Bergmann glial fibers. These results are discussed in terms of dissimilarities in microtubule organization and masking of epitopes by microtubule-associated proteins (MAPs) in individual cerebellar cells, which may be related to specific functional properties.
\end{abstract}

Microtubules are abundant cytoskeletal organelles that participate in a number of cellular functions, such as chromosomal movement, cell division, cell migration, intracellular transport, formation of cell shape, and secretion (Bray and Gilbert, 1981; Dustin, 1984; Littauer and Ginzburg, 1985). The nervous system consists of many neuronal cell types, most of which are anatomically and functionally unique. The progressive changes in cell shape that take place during neuronal morphogenesis depend on the redistribution of microtubules and probably on their interaction with other cytoskeletal elements. Thus, the nerve cell must be able to control the assembly of the desired microtubule during cell differentiation and regeneration or during any other changes that affect the plasticity of the neuronal network (I asek, 1981; Morrison et al., 1981; Ginzburg et al., 1983a, b; Neuman et al., 1983; Gard and Kirschner, 1985).

The diversity of microtubule functions suggests that not all microtubules are alike and that structurally distinct microtubules performing unique functions are present in different cell types and even within a single cell. Microtubule heterogeneity may arise from the assembly of different isotubulins and microtubule-associated proteins (MAPs; Binder et al., 1985). The functional specificity of tubulin isoforms is indicated by observations showing preferential tubulin synthesis for the formation of the outer doublet of flagellar microtubules (Fulton and Simp-

\footnotetext{
Received May 16, 1988; revised Sept. 12, 1988; accepted Oct. 20, 1988.

We thank Dr. O. Goldberg for her help in the synthesis of the peptides. This work was partially supported by a grant from the Forchheimer Center for Molecular Genetics and a grant from the Israel National Council for Research and Development and the European Economic Community.

Correspondence should be addressed to I. Ginzburg at the above address.

Copyright (C) 1989 Society for Neuroscience 0270-6474/89/061961-07\$02.00/0
}

son, 1976), the polymerization of particular isotubulins in cilia (Vallee et al., 1984), and the changes in the distribution of tubulin isoforms during brain development (Gozes and Littauer, 1978; Gozes et al., 1980). Moreover, in situ hybridization studies have revealed differences in the expression of $\alpha$ - and $\beta$-tubulin mRNA in different cell types in the developing cerebellum (Griffin et al., 1985; Ginzburg et al., 1986) and the developing brain (Miller et al., 1987). Monoclonal antibody to $\alpha$-tubulin has revealed heterogeneity of cytoplasmic microtubules within individual mouse or human cell types (Thompson et al., 1984) and suggested selective localization in axonal subpopulations (Cummings et al., 1983, 1984). In addition, the presence of distinct subsets of cellular microtubules was revealed by using antipeptide antibodies that specifically react with the tyrosinated and nontyrosinated C-terminal end of $\alpha$-tubulin (Gundersen et al., 1984) and antibodies specific for acetylated forms (Piperno and Fuller, 1985; Schulze et al., 1987). In contrast, comparison of the microtubule staining pattern obtained with monoclonal and polyclonal antibodies directed against $\beta$-tubulin has failed so far to detect differences in a wide variety of cells (Caceres et al., 1984; Cummings et al., 1984). Moreover, free intermingling of $\beta$-tubulin isotypes among functionally distinct microtubules has been demonstrated in transfected tissue culture cells (Bond et al., 1986; Joshi et al., 1987; Lewis et al., 1987).

Comparison of the amino acid sequence of $\beta$-tubulin from different species demonstrates a highly variable region at the C-terminal end (Krauhs et al., 1981; Hall et al., 1983; Farmer et al., 1984, 1986; Sullivan and Cleveland, 1984; Ginzburg et al., 1985) that is involved in binding of tau and MAP2 to tubulin (Ginzburg and Littauer, 1984; Littauer et al., 1985, 1986; Sackett et al., 1985; Serrano et al., 1985). In the present report we have elicited antibodies directed against synthetic peptides spanning the $\mathrm{C}$-terminal divergent and the preceding conserved region of $\beta$-tubulin and used them for histochemical analysis of rat brain cerebellum. The results demonstrate that the 3 antibody preparations recognize different microtubule structures localized in unique cell types of the cerebellum.

\section{Materials and Methods}

Synthesis of peptides corresponding to part of the C-terminal domain of brain $\beta$-tubulin. Peptides were synthesized by the solid phase method according to Merrifield (1965). The synthesized peptides were purified by gel filtration through a Sephadex G-25 (fine) column preequilibrated in $10 \%$ acetic acid or in $0.01 \mathrm{NHCl}$. The peptide containing fractions were lyophilized, and their composition was verified by amino acid analysis.

Preparation of antipeptide antibodies. The synthetic peptides were conjugated to a carrier protein, keyhole limpet hemeocyanin (KLH), using 4\% glutaraldehyde (Sutcliffe et al., 1983). The conjugates were mixed with Freund's complete adjuvant and injected subcutaneously into rabbits. The rabbits were boosted 3 times every 2 weeks in incom- 


$\begin{array}{ccc} & 416 \quad 425 \\ \text { Peptide } 1 & \text { NDLVSEYQQY } & \\ & 416 & 431 \\ \text { Peptide } 2 & \text { NDLVSEYQQYQDATAD } \\ & 426 & 445 \\ \text { Peptide } 4 & \text { QDATADEQGEFEEEEGEDEA }\end{array}$

Figure 1. Amino acid sequence of synthetic peptides corresponding to the $\mathrm{C}$-terminal region of $\beta$-tubulin. Peptides 1 and 2 correspond to positions $416-425$ and $416-431$, respectively, of porcine brain $\beta$-tubulin. Peptide 4 corresponds to positions $426-445$ of rat brain $\beta$-tubulin.

plete adjuvant and bled after 7 weeks, and the resultant antibodies were characterized by indirect radioimmunoassay and immunoblotting. Indirect radioimmunoassay was carried out by the solid phase method. Protein coating was performed at $10 \mu \mathrm{g} /$ well. For peptide coating, the plates were pretreated with $0.2 \%$ glutaraldehyde in $0.1 \mathrm{M} \mathrm{Na}$-phosphate

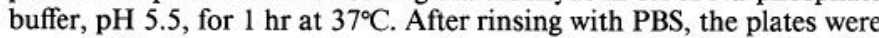
coated with the corresponding peptide at $5 \mu \mathrm{g} /$ well for $17 \mathrm{hr}$ at $4^{\circ} \mathrm{C}$. The plates were washed with PBS and blocked with a solution containing $1 \%$ BSA in PBS. After blocking, $25 \mu$ laliquots of serial diluted antibodies were added and the plates incubated for $4 \mathrm{hr}$ at $37^{\circ} \mathrm{C}$. The plates were then washed with $1 \%$ BSA in PBS, and $25 \mu \mathrm{l}$ aliquots of iodinated protein A (Pharmacia; 50,000 counts $/ \mathrm{min} /$ well) were added and incubated for $16 \mathrm{hr}$ at $4^{\circ} \mathrm{C}$. The plates were then washed with PBS, and the bound radioactivity in each well was determined.

Immunoblotting of rat brain tubulin, total microtubules, and extracts from whole brains or from isolated cerebella. Microtubule proteins were prepared from 12-d-old rats by 2 cycles of assembly and disassembly (Shelanski et al., 1973). PC-tubulin was isolated from microtubule preparations using a phosphocellulose column (Weingarten et al., 1975). The proteins were separated by $\mathrm{NaDodSO}_{4}-10 \%$ polyacrylamide slab gel electrophoresis (Laemmli, 1970). The proteins were transferred to ni-

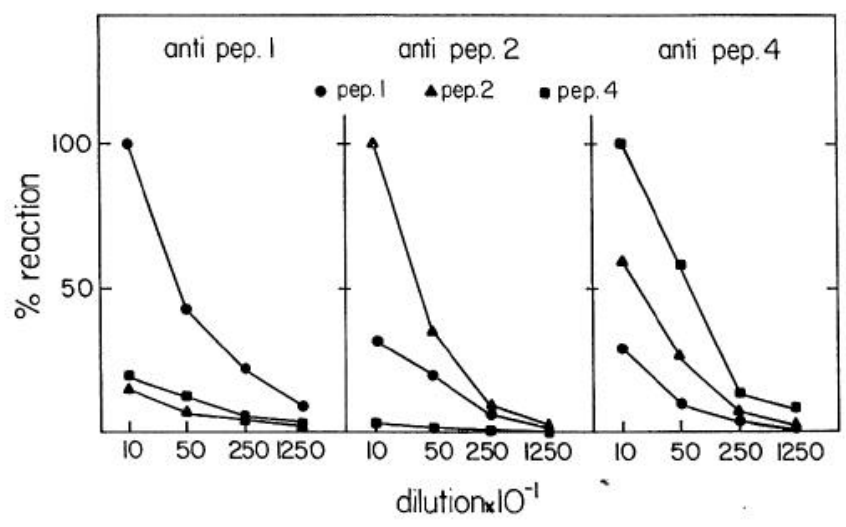

Figure 3. Antigenic specificity of antipeptide antibodies as tested by indirect radioimmunoassay.

trocellulose membrane for $16 \mathrm{hr}$ at $50 \mathrm{~mA}$ (Towbin et al., 1979) and then incubated with $1: 200$ diluted antibodies for $5 \mathrm{hr}$ at $37^{\circ} \mathrm{C}$. Iodinated protein A was added at $5 \times 10^{6}$ counts $/ \mathrm{min} / \mathrm{ml}$, and the washed nitrocellulose membrane was exposed for $16 \mathrm{hr}$ for autoradiography.

Immunohistochemical procedures. The cerebellum vermis from 14d-old rats was dissected and fixed in Bouin's solution for $18 \mathrm{hr}$, rinsed in $70 \%$ ethanol saturated with $\mathrm{LiCO}_{3}$, and embedded in paraffin. $5-\mu \mathrm{m}$ sections were mounted on gelatin-chrom-alum-coated microscope slides, deparaffinized in toluene, and rehydrated. The rehydrated slides were placed in $0.2 \mathrm{~N} \mathrm{HCl}$ for $20 \mathrm{~min}$ at room temperature to increase tissue permeability and then washed in TBS. The sections were stained according to the 3-layered method (Sternberger, 1979) using peroxidaseantiperoxidase reaction. The endogenous peroxidase level was reduced by incubating the sections with $0.6 \% \mathrm{H}_{2} \mathrm{O}_{2}$ in methanol, followed by

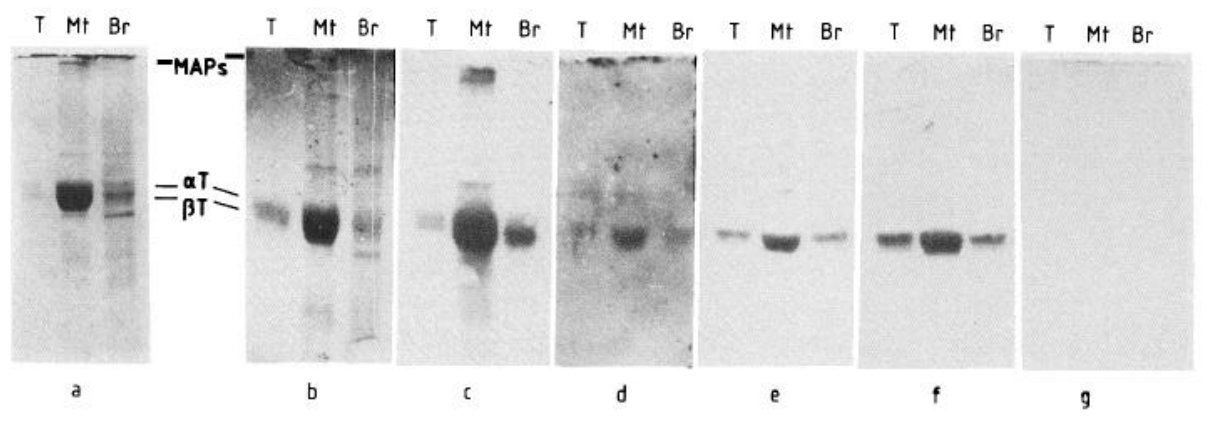

Figure 2. Immunoblot analysis of antibodies directed against synthetic peptides. Top, In each panel, PC-tubulin $(T)$, total microtubule proteins $(M t)$, and brain extract $(\mathrm{Br})$ were analyzed. $a$, Corresponding staining of the gel with Coomassie Brilliant blue; $b$, immunoblot stained with amido black; $c$, reaction with total MT antibodies; $d$, reaction with antipep-1 antibodies; $e$, reaction with antipep- 2 antibodies; $f$, reaction with antipep-4 antibodies; $g$, reaction with normal rabbit serum. Bottom, Tubulin ( $T$, microtubules $(M t)$, and total extract $(\mathrm{Cr})$ prepared from cerebellum. $a$, Immunoblot stained Ponceau S (Sigma); $b$, reaction with total MT antibodies; $c$, reaction with antipep-1 antibodies; $d$, reaction with antipep-2 antibodies; $e$, reaction with antipep-4 antibodies.

\section{$\mathrm{T} \mathrm{Mr} \mathrm{Cr}$}

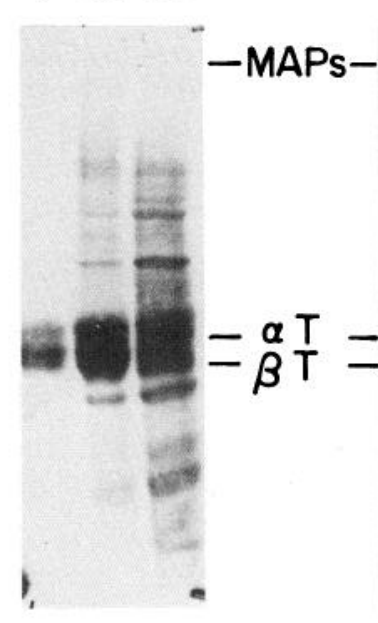

a
$\mathrm{T} \mathrm{Mt} \mathrm{Cr} T \mathrm{Mt} \mathrm{Cr}$

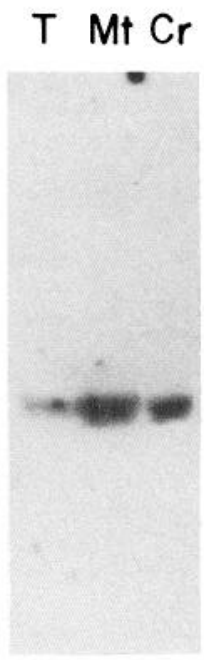

d b
C
$\mathrm{T} \mathrm{Mt} \mathrm{Cr}$

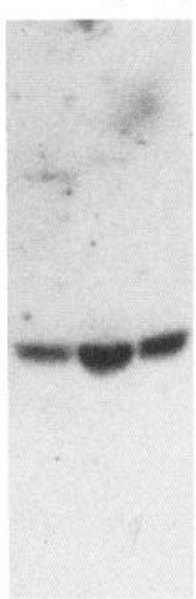


blocking with $1 \%$ of normal goat serum. The primary antibodies were diluted 1:50, 1:100, and 1:500 in $2 \%$ normal goat serum and reacted for $1 \mathrm{hr}$ at room temperature. The sections were washed with TBS and reacted with goat anti-rabbit IgG fraction diluted 1:50 for $30 \mathrm{~min}$ at room temperature. The sections were then washed again with TBS and incubated with rabbit peroxidase-antiperoxidase (Cappel) at 1:300 dilution for $30 \mathrm{~min}$ at room temperature. The sections were developed for $5 \mathrm{~min}$ by incubating with $0.44 \mathrm{mg} / \mathrm{ml} 3,3^{\prime}$-diaminobenzidine (Sigma) and $\mathrm{H}_{2} \mathrm{O}_{2}$ at a final concentration of $0.02 \%$. The reaction was stopped by dipping the slide in water, and the slice was stained with Mayer's hematoxylin and eosin and inspected under a light microscope. Rabbit antitubulin antibodies were from BioMakor.

\section{Results}

\section{Preparation and characterization of peptide antibodies}

We synthesized a number of peptides spanning the C-terminal region of $\beta$-tubulin for subsequent antibody generation. Three peptides covering different parts of this region were synthesized, as indicated in Figure 1. Peptide 1 and 2 correspond to porcine brain $\beta$-tubulin positions $416-425$ and $416-431$, respectively, and are highly conserved except for the aspartic acid residue at position 431 . On the other hand, peptide 4 corresponds to positions $426-445$ of the variable region of rat brain $\beta$-tubulin isoform T $\beta 15$ (Ginzburg et al., 1985), which corresponds to a major neuronal isotype (Farmer et al., 1986; Sullivan and Cleveland, 1986). The peptides were conjugated to a carrier protein, $\mathrm{KLH}$, and injected into rabbits. The resultant antibodies were characterized by immunoblotting, by indirect radioimmunoassay, and by immunohistochemical staining. Immunoblot analysis showed that the antibodies reacted only with $\beta$-tubulin subunit from total brain extract, purified rat brain tubulin, or total assembled microtubules (Fig. 2, top). Similar results were obtained from extracts of MT prepared from rat cerebella (Fig. 2 , bottom). The antibodies did not cross-react with $\alpha$-tubulin or with other components of the microtubules, and control serum was not immunoreactive. Absorption of the antibodies with MT preparations markedly reduced the antibody binding activity.

The specificity of the antibodies towards the relevant peptides was examined by indirect radioimmunoassay. Cross-reactivity between the 3 antibodies was assayed by reacting each antibody against all 3 peptides (Fig. 3). In these tests, antipeptide 1 recognized peptide 1 only, while antipeptide 2 had some crossreactivity towards peptide 1 , as expected from the overlap of their amino acid sequences. In addition, antipeptide 4 displayed some cross-reactivity towards peptide 2 . These cross-reactions could be decreased at higher dilutions of the serum (Fig. 3) and were therefore chosen for subsequent studies.

\section{Localization of distinct microtubules in identified cerebellar cells}

The cellular distribution of the $3 \beta$-tubulin immunoreaction products was determined by indirect peroxidase-antiperoxidase staining in 5- $\mu \mathrm{m}$ sections of Bouin's-fixed, paraffin-embedded sections of cerebellum of 14-d-old Fischer rats. The 14-d-old cerebellum was chosen for these studies because all of the adult cell types are represented, as are the external granular layer (EGL) cells, which are not present in the adult cerebellum. The germinal cells in the EGL are proliferating, and the prenatally formed Purkinje, Golgi, deep cerebellar nuclei, and glial cells are still differentiating. The Bergmann glial fibers of Golgi II cells that reside in the Purkinje monolayer have extended processes to the pial surface. The highly structured architecture of the cerebellum and some of the developmental events that con-

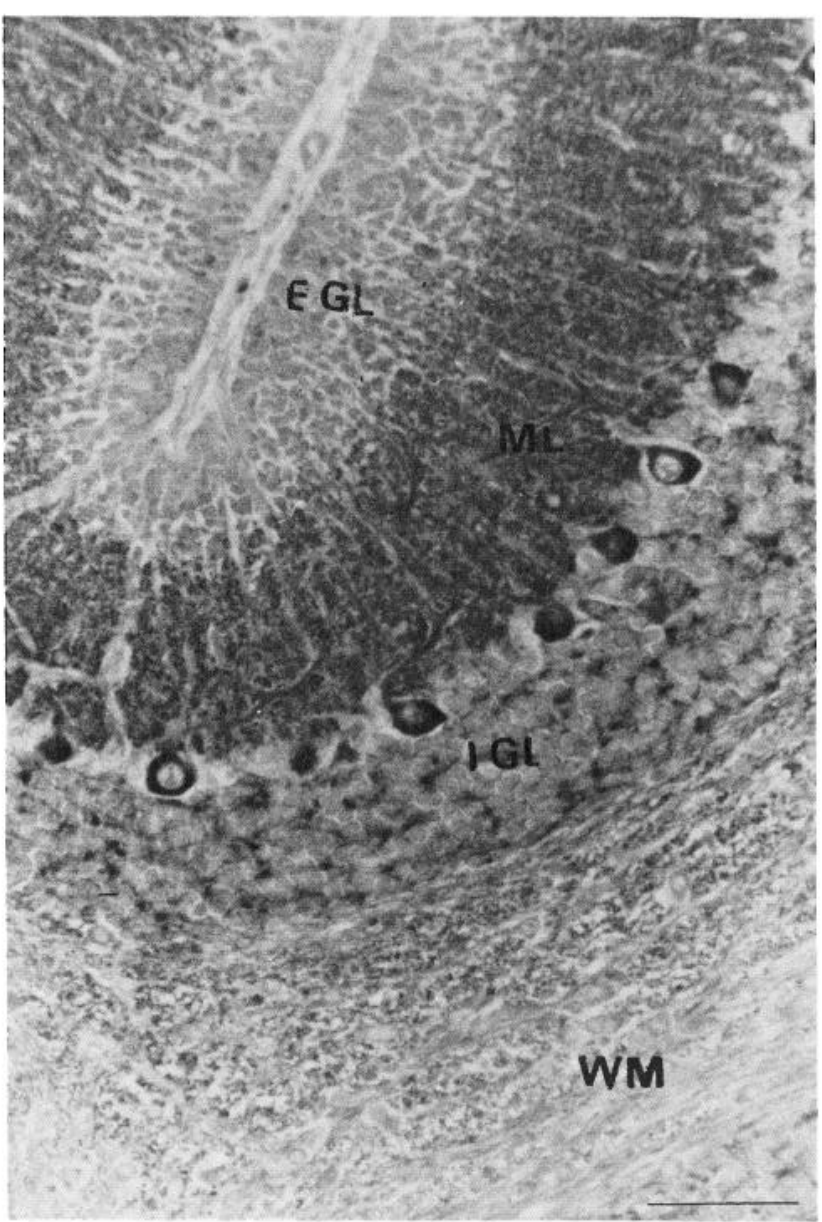

Figure 4. Cerebellar section from 14-d-old rats reacted with polyclonal antibodies directed against tubulin (BioMakor). Scale bar, $50 \mu \mathrm{m}$.

tribute to its organization are well characterized (for a summary, see Palay and Chan-Palay, 1974).

Using rabbit antiperoxidase staining (Sternberger, 1979), the different antibodies directed against the peptides revealed distinct localization of microtubules in different cell types, while polyclonal tubulin antibodies showed staining of all cerebellar cells (Fig. 4). No specific immunoreactive products were detected when either sera from nonimmunized rabbits or KLHcarrier sera were used in place of the immune sera (see Fig. 8). Preincubation of each antiserum with its corresponding peptide abolished the specific staining of the cerebellar cells (not shown).

Figure 5 shows that antibodies directed against peptide 1 are highly specific. Heavy staining was observed in Purkinje cell axons and their dendrites. Most of the Purkinje cell bodies were stained as well, and in some areas it was possible to visualize the axon hillock extending from the Purkinje cell. Particularly heavy staining was observed in the axons in the internal granular layer (IGL) and the white matter. The same results were obtained with several batches of antipeptide 1 obtained from different rabbits.

Figure 6 demonstrates that antibodies directed against peptide 4 selectively stained Bergmann glial fibers in the molecular layer. In some cases it is even possible to detect the staining of cells tentatively identified as glia in the IGL and white matter. Staining was reminiscent of that seen after immunoreaction of neonatal cerebellum with antibodies directed against glial fibrillary 

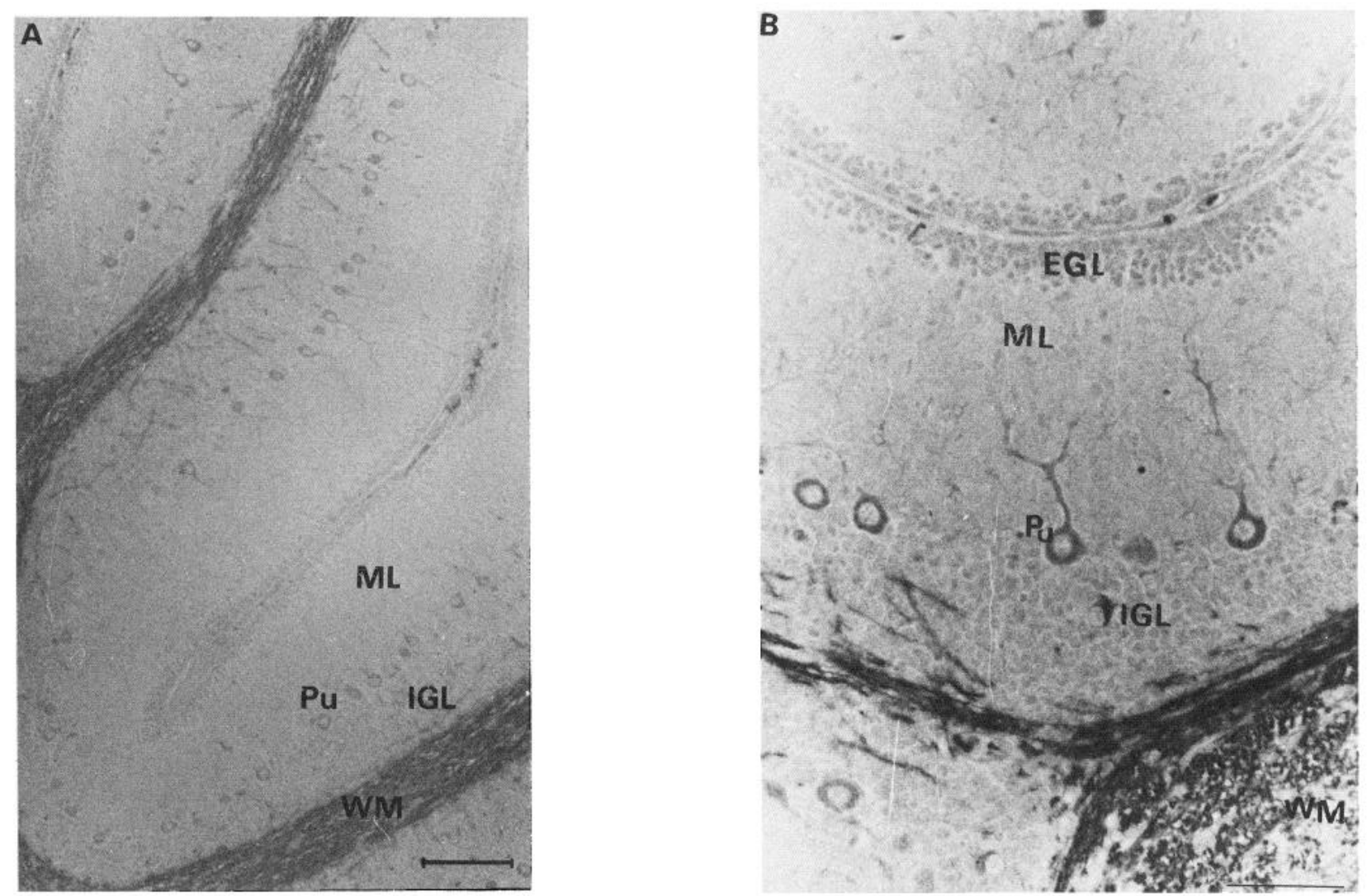

Figure 5. Section of rat cerebellum reacted with peptide 1 antibodies. $A$, Lower magnification; bar, $100 \mu \mathrm{m} . B$, Higher magnification; bar, $50 \mu \mathrm{m}$. $P u$, Purkinje cells; $W M$, white matter; $E G L$, external granular layer; $I G L$, internal granular layer; $M L$, molecular layer.
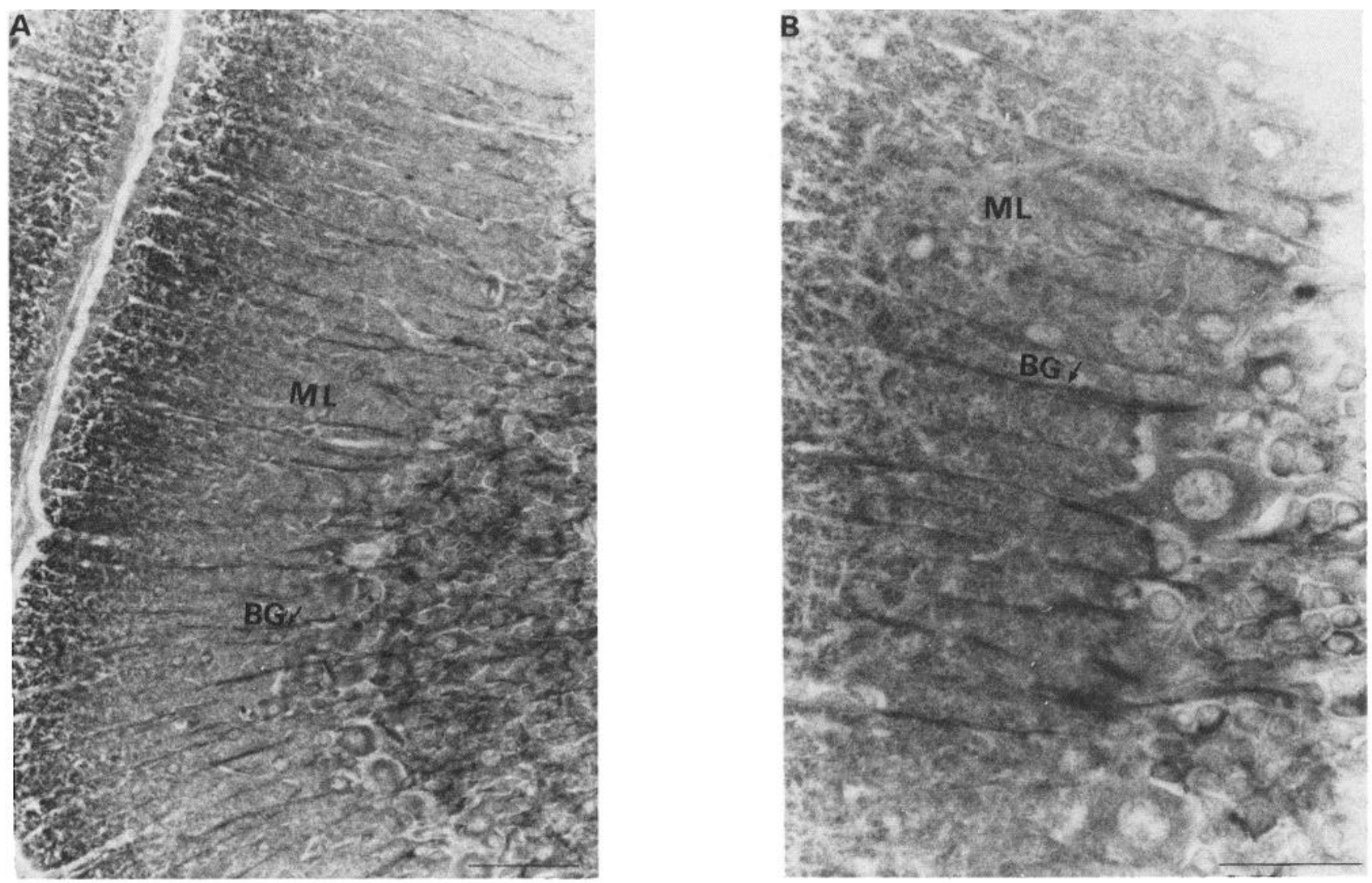


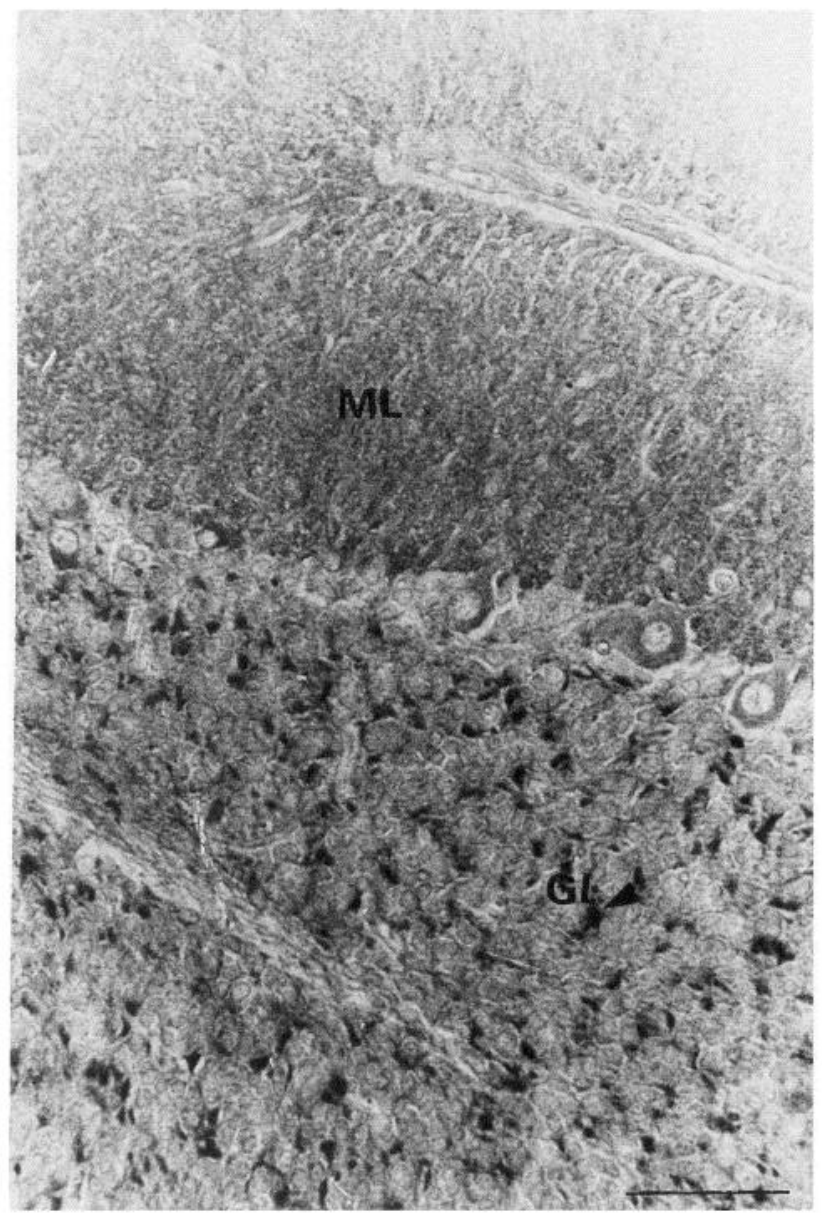

Figure 7. Section of rat cerebellum reacted with peptide 2 antibodies. $M L$, Molecular layer; $I G L$, internal granular layer; $G L$, glomeruli. Scale bar, $50 \mu \mathrm{m}$.

acidic protein (Griffin et al., 1983) or vimentin (W. S. T. Griffin, unpublished observations).

The third antibody, antipeptide 2 , heavily stained the synaptic glomeruli in the IGL of the cerebellum and, to a lesser extent, the Golgi cells and parallel fibers (Fig. 7). No staining was observed above the background in the molecular layer or in the white matter. The glomeruli are the principal sites where mossy fiber terminals make their synaptic terminations and are seen under a light microscope as small clear spaces within the granular layer.

\section{Discussion}

The mammalian brain is unique in its high diversity of cell types. The development of distinct classes of brain cells involves 3 major successive or simultaneous cellular events. A phase of intensive cell division is followed by a phase of cell migration and finally a differentiation step into mature cells carrying out special tasks. In recent years, it has become clear that the unique cell shape of neurons is determined to a large extent by the neuronal cytoskeleton. It has been established that different classes of microtubules are localized in distinct domains of the

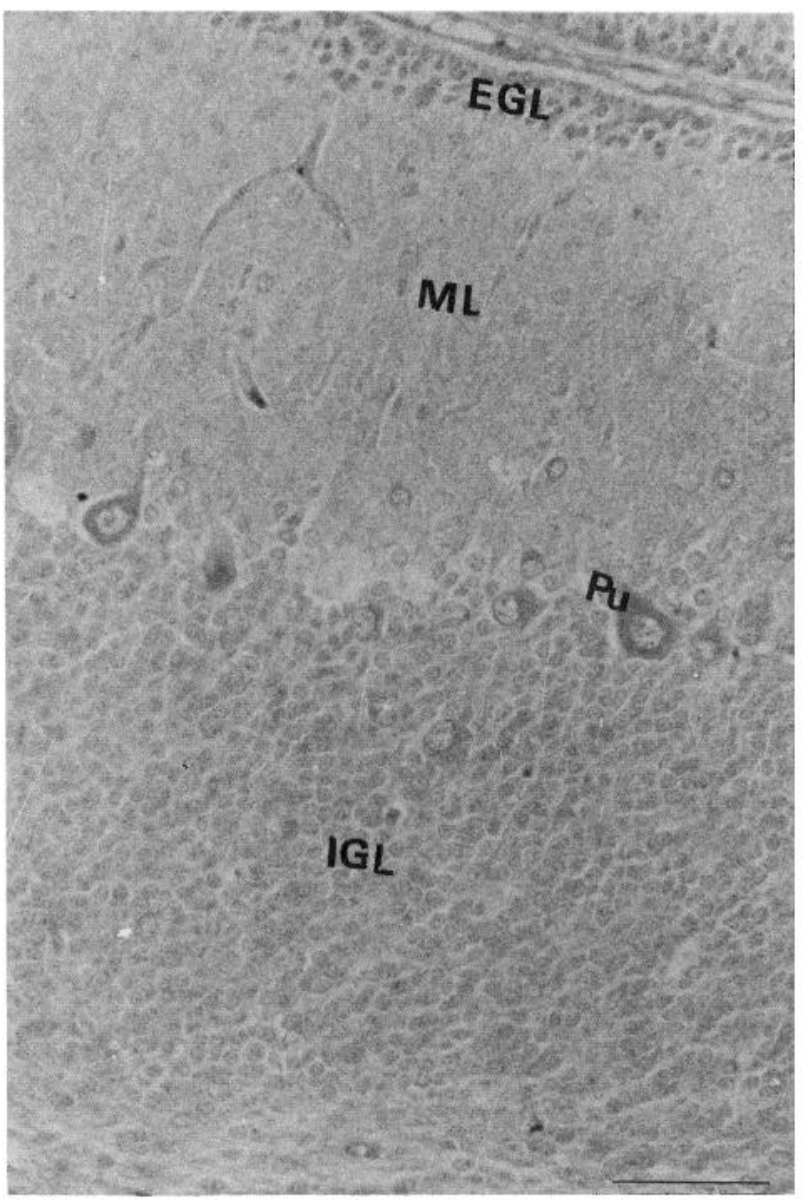

Figure 8. Section of rat cerebellum reacted with normal rat serum. $P u$, Purkinje cells; $E G L$, external granular layer; $I G L$, internal granular layer; $M L$, molecular layer.

same single cell, and distribution of MAPs (including MAP1, MAP2, and tau) is different in dendrites as compared to axons (Matus et al., 1983; Caceres et al., 1984; DeCamilli et al., 1984; Binder et al., 1985).

Three synthetic peptides spanning the $\mathrm{C}$-terminal region were used to generate antibodies. The 3 antibodies displayed a remarkable specificity in detecting different microtubules in different cells from the rat cerebellum. Antibodies directed against peptide 1 primarily stained Purkinje cells and their dendrites and axons. It should be noted that the Purkinje cells are the sole source for outside projecting axons from the cerebellar cortex. Peptide 2 antibodies stained microtubules in the glomeruli and, to a lesser extent, the Golgi cells and parallel fibers. It is interesting to note that similar glomeruli structures were identified with specific antiserum to synaptic glomeruli from rat cerebellum (Goridis et al., 1978), which is not detected until postnatal days 14-15 when these synapses are fully developed. Antibodies directed against peptide 4 preferentially stained Bergmann glial fibers, which have been proposed to act as guides for migrating neurons in the cerebellum (Sommer et al., 1981).

Although the peptides used as antigens in these experiments share some common amino acid sequence, the antibody cross-

Figure 6. Section of rat cerebellum reacted with peptide 4 antibodies. $A$, Lower magnification; bar, $50 \mu$ m. $B$, Higher magnification; bar, $25 \mu$ m. $B G$, Bergmann glial fibers; $M L$, molecular layer. 
reactivity could be reduccd by proper dilution (Fig. 3). Under these conditions, the antibodies show specificity toward different microtubules in individual cerebellar cell types. The specific staining with antipeptide 4 could arise from its reaction with the divergent amino acid sequence at the C-terminus of $\mathrm{T} \beta 15$ isoform. An alternative explanation would involve microtubule structures that differ by their accessibility to the antibody. The specificity of antipeptide 1 and antipeptide 2 that were raised against conserved sequences may arise from differences in the tertiary structure of the various microtubules. Whether the differences revealed by the various antibodies reflect dissimilarities in microtubule organization resulting from subtle changes in amino acid sequence or are a result of the masking of an epitope(s) due to binding of specific MAPs or other ligands remains to be determined. The specificity of the various antibodies would indicate differential distribution of microtubules in individual ccrcbcllar cclls. The use of specific antibodies may thus contribute to elucidation of the roles of unique microtubule structures in cytoskeletal function during neuronal differentiation and may allow the analysis of the expression of specific tubulin isotypes in various cell types.

\section{References}

Binder, L. I., A. Frankfurter, and L. I. Rebhun (1985) The distribution of tau in the mammalian central nervous system. J. Cell Biol. 101: 1371-1378.

Bond, J. F., J. L. Fridovich-Keil, L. Pillus, R. C. Mulligan, and F. Solomon (1986) A chicken-yeast chimeric beta-tubulin protein is incorporated into mouse microtubules in vivo. Cell 44: 461-468.

Bray, D., and D. Gilbert (1981) Cytoskeletal elements in neurons. Annu. Rev. Neurosci. 4: 505-523.

Caceres, A., L. I. Binder, M. R. Payne, P. Bender, L. Rebhun, and O. Steward (1984) Differential subcellular localization of tubulin and the microtubule-associated protein MAP2 in brain tissue as revealed by immunohistochemistry with monoclonal hybridoma antibodies. J. Neurosci. 4: 394-410.

Cummings, R., R. D. Burgoyne, and N. A. Lytton (1983) Axonal subpopulations in the central nervous system demonstrated using monoclonal antibodies against alpha-tubulin. Eur. J. Cell Biol. 31: 241248.

Cummings, R., R. D. Burgoyne, and N. A. Lytton (1984) Immunocytochemical demonstration of alpha tubulin modification during axonal maturation in the cellular cortex. J. Cell Biol. 98: 347-35 1 .

DeCamilli, P., P. E. Miller, F. Navone, N. E. Theurkauf, and R. B. Vallee (1984) Distribution of microtubule-associated protein in the nervous system of the rat studied by immunofluorescence. Neuroscience 11: 819-846.

Dustin, P. (1984) Microtubules, Springer-Verlag, New York.

Farmer, S. R., J. F. Bond, G. S. Robinson, D. Mbangkollo, M. J. Fenton, and E. M. Berkowitz (1984) Differential expression of the rat $\beta$-tubulin multigene family. In Molecular Biology of the Cytoskeleton, G. G. Borisy, D. W. Cleveland, and D. W. Murphy, eds., pp. 333-342, Cold Spring Harbor Laboratory Press, New York.

Farmer, S. R., G. S. Robinson, D. Mbangkollo, J. F. Bond, G. B. Knight, M. J. Fenton, and E. M. Berkowitz (1986) Differential expression of $\beta$-tubulin multigene family during rat brain development. Ann. NY Acad. Sci. 466: 41-50.

Fulton, C., and P. A. Simpson (1976) Selective synthesis and utilization of flagellar tubulin. In The Multi-Tubulin Hypothesis in Cell Motility, R. Goldman, T. Pollard, and J. Rosenbaum, eds., pp. 9871005, Cold Spring Harbor Laboratory Press, New York.

Gard, D. L., and M. W. Kirschner (1985) Polymer-dependent phosphorylation of beta-tubulin accompanies differentiation of mouse neuroblastoma line. J. Cell Biol. 100: 764-774.

Ginzburg, I., and U. Z. Littaucr (1984) Expression and Cellular regulation of microtubule proteins. In Molecular Biology of the Cytoskeleton, G. G. Borisy, D. W. Cleveland, and D. P. Murphy, eds., pp. 357-366, Cold Spring Harbor Laboratory Press, New York.

Ginzburg, I., S. Rybak, Y. Kimhi, and U. Z. Littauer (1983a) Biphasic regulation by dibutyryl cyclic AMP of tubulin and actin mRNA levels in neuroblastoma. Proc. Natl. Acad. Sci. USA 80: 4243-4247.

Ginzburg, I., T. Scherson, S. Ryback, Y. Kimhi, D. Neuman, M. Schwartz, and U. Z. Littauer (1983b) Expression of mRNA for microtubule proteins in the developing nervous system. Cold Spring Harbor Symposium on Quantitative Biology. Mol. Biol. 48: 783-790.

Ginzburg, 1., A. Teichman, H. J. Dodemont, L. Behar, and U. Z. Littauer (1985) Regulation of three beta-tubulin mRNAs during rat brain development. EMBO J. 4: 3667-3673.

Ginzburg, I., A. Teichman, W. S. T. Griffin, and U. Z. Littauer (1986) Differential expression of alpha tubulin mRNA in rat cerebellum as revealed by in situ hybridization. FEBS Lett. 194: 161-164.

Goridis, C., J. Martin, and M. Schachner (1978) Characterization of an antiserum to synaptic glomeruli from rat cerebellum. Brain Res. Bull. 3: 45-52.

Gozes, I., and U. Z. Littauer (1978) Tubulin microheterogeneity increases with rat brain maturation. Nature 276: 411-413.

Gozes, I., A. de Baetselier, and U. Z. Littauer (1980) Translation in vitro of rat brain mRNA. Coding for a variety of tubulin forms. Eur. J. Biochem. 103: 15-20.

Griffin, W. S. T., M. Alejos, and M. R. Morrison (1983) Brain protein and messenger RNA identification in the same cell. Brain Res. Bull. 10: $597-601$.

Griffin, W. S. T., M. A. Alejos, E. J. Cox, and M. R. Morrison (1985) The differential distribution of $\beta$-tubulin $\mathrm{mRNA}$ in individual mammalian brain cells. J. Cell Biochem. 27: 205-214.

Gundersen, G. G., M. H. Kalnoski, and J. C. Bulinski (1984) Distinct populations of microtubules: Tyrosinated and nontyrosinated alphatubulin are distributed differently in vivo. Cell 38: 779-789.

Hall, J. L., L. Dudley, P. R. Dobner, S. A. Lewis, and N. J. Cowan (1983) Identification of two human beta-tubulin isotypes. Mol. Cell Biol. 3: 854-862.

Joshi, H. C., T. J. Yen, and D. W. Cleveland (1987) In vivo coassembly of a divergent $\beta$-tubulin subunit $(\mathrm{C} \beta 6)$ into microtubules of different function. J. Cell Biol. 105: 2179-2190.

Krauhs, E., M. Little, T. Kempf, R. Hofer-Warbinek, W. Ade, and H. Ponstingl (1981) Complete amino acid sequence of beta tubulin from porcine brain. Proc. Natl. Acad. Sci. USA 78: 4156-4160.

Laemmli, U. K. (1970) Cleavage of structural proteins during the assembly of the head of bacteriophage $T_{4}$. Nature 227:680-685.

Lasek, R. J. (1981) The dynamic ordering of neuronal cytoskeleton. Neurosci. Res. Prog. Bull. 19: 7-31.

Lewis, S. A., W. Gu, and N. J. Cowan (1987) Free intermingling of mammalian $\beta$-tubulin isotypes among functionally distinct microtubules. Cell 49: 539-543.

Littauer, U. Z., and I. Girlzburg (1985) Expression of microtubule proteins in brain. In Gene Expression in Brain, C. Zomzely-Neurath and W. A. Walker, eds., pp. 125-156, Wiley, New York.

Littauer, U. Z., D. Giveon, M. I hierauf, I. Ginzburg, and H. Ponstingl (1985) Tubulin binding sites for microtubule associated proteins. In Microtubule and Microtubule Inhibitors, M. De Brabander and I, De Mey, eds., pp. 171-176, Elsevier, Amsterdam.

Littauer, U. Z., D. Giveon, M. Theirauf, I. Ginzburg, and H. Ponsting (1986) Common and unique tubulin binding sites for microtubule associated proteins. Proc. Natl. Acad. Sci. USA 83: 7162-7166.

Matus, A., G. Huber, and R. Bernhardt (1983) Neuronal microdifferentiation. Cold Spring Harbor Symposium on Quantitative Biology. Mol. Neurobiol. 48: 775-782.

Merrifield, R. B. (1965) Automated synthesis of peptides. Science 150: 178-185.

Miller, F. D., C. C. G. Naus, M. Durand, F. E. Bloom, and R. J. Milner (1987) Isotypes of $\alpha$-tubulin are differentially regulated during neuronal maturation. J. Cell Biol. 105: 3065-3071

Morrison, M. R., S. Pardue, and W. S. T. Griffin (1981) Developmental alterations in the levels of translationally active messenger RNAs in postnatal rat cerebellum. J. Biol. Chem. 256: 3550-3556.

Neuman, D., T. Scherson, I. Ginzburg, U. Z. Littauer, and M. Schwartz (1983) Regulation of mRNA levels for microtubule proteins during nerve regeneration. FEBS Lett. 162: 270-276.

Palay, S., and V. Chan-Palay (1974) Cerebellar Cortex, Springer-Verlag, New York.

Piperno, G., and M. T. Fuller (1985) Monoclonal antibodies specific for an acetylated form of $\alpha$-tubulin recognize the antigen in cilia and flagella from a variety of urganisms. J. Cell Biol. 101: 2085-2094.

Sackett, D. L., B. Bhattacharyya, and J. Wolff (1985) Tubulin subunit 
carboxyl termini determine polymerization efficiency. J. Biol. Chem. 260: 43-45.

Schulze, E., D. J. Asai, J. C. Bulinski, and M. W. Kirschner (1987) Posttranslational modification and microtubule stability. J. Cell Biol. 105: 2167-2177.

Serrano, L., E. Montejo de Garcini, M. A. Hernandez, and J. Avila (1985) Localization of the tubulin binding site for tau protein. Eur. J. Biochem. 153: 595-600.

Shelanski, M. L., F. Gaskin, and C. R. Cantor (1973) Microtubule assembly in the absence of added nucleotides. Proc. Natl. Acad. Sci. USA $70: 765-768$

Sommer, I., C. Lagenaur, and M. Schachner (1981) Recognition of Bergmann glial and ependymal cells in the mouse nervous system by monoclonal antibody. J. Cell Biol. 90: 448-458.

Sternberger, L. A. (1979) Immunocytochemistry, Wiley, New York.

Sullivan, K. F., and D. W. Cleveland (1984) Sequence of a highly divergent beta-tubulin gene reveals regional heterogeneity in the betatubulin polypeptide. J. Cell Biol. 99: 1754-1760.

Sullivan, K. F., and D. W. Cleveland (1986) Identification of conserved isotype-defining variable region sequences for vertebrate $\beta$-tubulin polypeptide classes. Proc. Natl. Acad. Sci. USA 83: 4327-4331.
Sutcliffe, J. G., R. J. Milner, T. M. Shinnick, and F. E. Bloom (1983) Identifying the protein products of brain-specific genes with antibodies to chemically synthesized peptides. Cell 33: 671-682.

Thompson, W. C., D. J. Asai, and D. H. Carney (1984) Heterogeneity among microtubules of the cytoplasmic microtubule complex detected by a monoclonal antibody to alpha-tubulin. J. Cell Biol. 98. $1017-1025$.

Towbin, H., T. Staehelin, and J. Gordon (1979) Electrophoretic transfer of protein from polyacrylamide gels to nitrocellulose sheets. Procedure and some applications. Proc. Natl. Acad. Sci. USA 76: 43544356.

Vallee, R. B., G. S. Bloom, and F. C. Luca (1984) Differential cellular and subcellular distribution of microtubule associated proteins. In Molecular Biology of the Cystoskeleton, G. G. Borisy, D. W. Cleveland, and D. B. Murphy, eds., pp. 111-130. Cold Spring Harbor Laboratory Press, New York.

Weingarten, M. D., A. H. Lockwood, S. Hwo, and M. W. Kirschner (1975) A protein factor essential for microtubule assembly. Proc. Natl. Acad. Sci. USA 72: 1858-1862. 